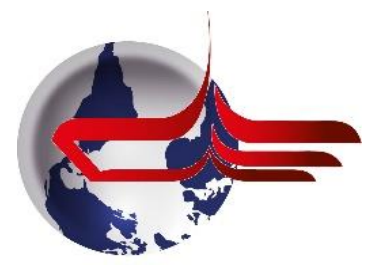

Turkish Journal of Educational Studies, 5 (3) Ekim 2018

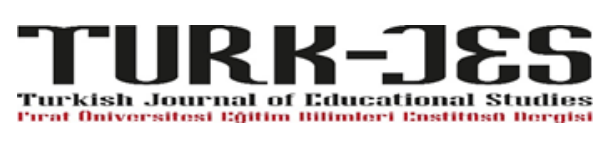

Research Article / Araştırma Makalesi

Article Info/Makale Bilgisi

Received/Geliş: Ekim 2018 Accepted/Kabul: Ekim 2018

\title{
Öğretmen Adaylarının Benlik Saygıları, Narsisizm Düzeyleri ve Öğrenme- Öğretme Yaklaşımları Arasındaki İlişki Üzerine Bir İnceleme*
}

\section{An Investigation on the Relationship between Preservice Teachers' Self-Esteem, Narcissism Levels and Conceptions of Learning and Teaching}

Bekir Kürşat DORUK ${ }^{* *}$

\section{$\ddot{O} z$}

Araştırmada öğretmen adaylarının benlik saygıları, narsisizm düzeyleri ve öğrenme-öğretme yaklaşımları arasındaki ilişkiyi incelemek amaçlanmıştır. Bunun için Rokeach’ın (1968) inanç sistemi yaklaşımına dayanarak bir yapısal model önerilmiştir. Üç ayrı veri toplama aracının kullanıldığı çalışmaya 923 öğretmen adayı katılmıştır. Araştırmanın sonuçları öğretmen adaylarının benlik saygılarının narsisizm düzeyleriyle pozitif yönde ilişkiye sahip olduğunu göstermektedir. Ayrıca çalışmada öğretmen adaylarının benlik saygıları ve narsisizm düzeylerinin gelecekteki sınıflarında uygulayacakları öğrenme öğretme yaklaşımı tercihinde etkili olduğunu gösterir deliller elde edilmiştir. Bulgular, öğretmen adaylarının benlik saygıları yükseldikçe yapılandırmacı öğrenme-öğretme yaklaşımını benimseme düzeylerinin arttığını, narsisizm düzeyleri yükseldikçe de geleneksel öğrenme-öğretme yaklaşımını daha fazla benimsemekte olduklarını göstermektedir. Çalışmada elde edilen sonuçlar doğrultusunda öğretmen yetiştirme alanına katkı sağlayacak bazı önerilerde bulunulmuştur.

Anahtar Kelimeler: İnanç sistemi, Benlik saygısı, Narsisizm, Öğrenme-öğretme anlayışı, Yapılandırmacı yaklaşım, Geleneksel Yaklaşım, Öğretmen adayları.

\footnotetext{
Abstract

* Bu çalışma, Bolu Abant İzzet Baysal Üniversitesi Bilimsel Araştırma Projeleri Birimi tarafindan 2018.02.01.1353 nolu proje kapsamında desteklenmiştir.

** Doç.Dr. Bolu Abant İzzet Baysal Üniversitesi, Eğitim Fakültesi, Matematik Eğitimi Anabilim Dalı, El-mek: bkdoruk@gmail.com

*** Doç.Dr. Bolu Abant İzzet Baysal Üniversitesi, Eğitim Fakültesi, Fen Bilgisi Eğitimi Anabilim Dalı, El-mek: eralpbahcivan@hotmail.com

***** Dr.Öğr.Üyesi Nuh YAVUZALP, Bolu Abant İzzet Baysal Üniversitesi, Eğitim Fakültesi, BÖTE Anabilim Dalı, El-mek: nuhyavuzalp@gmail.com
} 
The aim of this study was to investigate the relationship among pre-service teachers' self-esteem, narcissism levels and conceptions of teaching-learning. For this purpose, a structural model was proposed based on Rokeach's (1968) belief system approach. 923 pre-service teachers participated in the study. The results of the study showed that self-esteem of the pre-service teachers had a positive relationship with levels of narcissism. In addition, the study showed that self-esteem and narcissism levels of pre-service teachers might be effective on their choice of teaching-learning approach in their future practices. The findings showed that when self-esteem of pre-service teachers increased, the adoption of constructivist teaching-learning approach increased. As the level of narcissism increased, they were more likely to adopt the traditional teaching and learning approaches. In line with the results obtained in the study, some suggestions were presented to contribute to teacher training.

Keywords: Belief system, Self-esteem, Narcissism, Conceptions of teaching and learning, Constructivist approach, Traditional approach, Pre-service teachers.

\section{GİRIŞ}

Öğretmenlerin uygulamalarının öğrencilerin öğrenmeleri ve başarıları üzerindeki önemli etkisi (Wenglinsky, 2002) ve öğretmenlerin inançlarının da bu uygulamaları şekillendirmedeki rolü araştırmacıları öğretmenlerin (ve öğretmen adaylarının) inançları ve bu inançların onların öğretim davranışlarına etkilerini araştırmaya yöneltmiştir (Pajares, 1992). Ancak öğretim uygulamalarını etkileyebilecek nitelikteki öğretmen inançlarının sayılamayacak kadar çok oluşu nitelikli öğretmen eğitimi için bu inançlar arasındaki hiyerarşik ilişkinin belirlenmesini gerekli kılmaktadır (Rokeach, 1968). Psikoloji literatüründe inançların bu hiyerarşik yapılanmasını aydınlatmaya yönelik çalışmalar yapılmasına karşın eğitim literatüründe öğretmen adaylarının öğretime yönelik davranışlarını şekillendiren inançların hiyerarşik düzenini inceleyen az sayıda çalışmaya rastlanmaktadır (Bahcivan ve Cobern, 2016)

Bireyin kendi benliği hakkındaki inançları onun eğitim yaşamına yön veren en önemli etkenlerden biridir (Pajares, 1992). Buradan hareketle öğretmen adaylarının kendi benlikleri hakkındaki inançlarının, gelecekteki öğrencilerinin eğitim yaşamında önemli rol oynayacak olan öğrenme-öğretme yaklaşımı tercihleri üzerine etkilerinin incelemeye değer bir konu olacağı düşünülebilir. Öte yandan bireyin kendi benliğiyle ilgili psikoloji literatüründe önemli bir yer tutan kavramlardan ikisi benlik saygısı ve narsisizmdir (Campbell, Rudich ve Sedikides, 2002). Bu iki kavram arasında doğrudan bağlantı bulunduğu ve yüksek benlik saygısının narsisizmi de içeren heterojen bir yapısı olduğu bilinmektedir (Atay, 2010; Baumeister, Campbell, Krueger ve Vohs, 2003). Ancak narsisizmin yüksek benlik saygısından kritik bazı farklılıkları vardır ki bu farklar bireyin kişilerarası ilişkilerinde önemli sonuçlar doğuruyor görünmektedir (Campbell vd., 2002). Bu kavramlardan benlik saygisıyla ilgili eğitim literatüründe sınırlı sayıda çalışmaya rastlanmakla birlikte bunların öğretmenlerin öğretime yönelik inançlarıyla ilişkilendirilmediği görülmektedir. Eğitim ve öğretmen yetiştirme literatüründe narsisizm ile ilgili çalışmalara ise daha nadir rastlanabilmektedir. Psikoloji literatüründe bireyin günlük 
ve iş yaşamındaki etkileri bakımından yoğun bir şekilde araştırılan bu kavramların (Atay, 2009; Baumeister vd., 2003) öğretmen adaylarının sınıf ortamında benimseyecekleri yaklaşımlarla ilişkisini araştırmanın öğretmen yetiştirme alanına katkı sağlayacağı düşünülebilir. Bu bağlamda araştırmada ögretmen adaylarının benlik saygıları, narsisizm düzeyleri ve öğretme-öğrenme yaklaşımları arasındaki ilişkiyi ortaya koymak, böylece öğretmen adaylarının öğretimle ilgili sahip oldukları hiyerarşik düzendeki inanç sisteminin varlığı için deliller sunmak amaçlanmıştır.

\section{Öğretmen İnançları ve İnanç Sistemleri}

Genel anlamda inanç bireyin kendisi ve içinde yaşadığı çevre hakkındaki öznel yargıları olarak tanımlanabilir (Fishbein ve Ajzen, 1975). Araştırmalar öğretmen adaylarının inançlarının öğretim uygulamaları üzerinde önemli etkileri olduğunu göstermektedir (Pajares, 1992). Öğretmen yetiştirme programlarının önemli bir görevi de öğretmen adaylarının inançlarını, öğrenme ve öğretmeyi destekleyici yönde değiştirmeye ve geliştirmeye çalışmaktır. Fakat öğretmen adayları çoğu zaman önceden sahip oldukları inançları değiştirmek konusunda direnç gösterirler (Doruk, 2014). Aynı zamanda öğretmen adaylarının inançlarının öğretim pratikleri üzerindeki etkisi karmaşık bir yapıya sahiptir ve kimi zaman öğretmen adaylarının inançları ile öğretim uygulamaları arasında tutarsızlıklar görülebilmektedir (Doruk, 2014; Kane, Sandretto ve Heath, 2002). Bu anlamda öğretmen adaylarının inançları arasındaki ilişkilerin ve hiyerarşinin belirlenmesi, öğretim uygulamalarında hangilerinin daha etkili olduğunu ya da değişime direnç gösterdiğini belirleme noktasında önem kazanmaktadır.

Rokeach'a (1968) göre insanlar yüzlerce inanca sahiptir. Bu inançlar, atom modelinde olduğu gibi, bazıları merkezi (central) iken diğerleri çevrel (peripheral) olmak üzere hiyerarşik bir yapı oluştururlar. Bu hiyerarşik yapıda merkezde bulunan inançlar, çevrel inançlar üzerinde etki sahibidir. Bu noktada, yukarıda bahsedilen öğretmen adaylarının inançları ve uygulamaları arasındaki tutarsızlıkta (Doruk, 2014; Kane, Sandretto ve Heath, 2002), hiyerarşik yapıdaki inançlardan, daha merkezi olan bazı inançların (Rokeach, 1968) öğretmen adaylarının öğrenme-öğretme hakkındaki inançları üzerinde etkilerinin söz konusu olup olmadığı sorusu akla gelmektedir. Psikoloji literatüründe inançların hiyerarşik yapıları hakkında birçok aydınlatıcı çalışmaya rastlanırken, öğretmen yetiştirme alanında öğretmen adaylarının öğretmeye dair inançlarının bu bağlamda incelendiği az sayıda çalışma gerçekleştirilmiştir (Bahcivan ve Cobern, 2016).

Rokeach'ın (1968) ortaya koyduğu inanç sisteminde 5 tip inanç bulunmaktadır. A ve B tipi inançlar insanların temel doğrularını ve kendi benliklerinin doğası hakkındaki hükümlerini kapsar. C tipi inançlar dünyayı daha rasyonel yapmak için dikkate alınması gereken hükümlere karşılık gelen otorite inançlardır. D tipi inançlar otorite inançlarından türetilmiş olan ideolojik inançları içerir. E tipi inançlar ise kişisel haz ve tatlara yönelik inançları kapsar. Merkezi inançlar çevrel olanlarla kıyaslandığında diğer inançlarla daha fazla bağlantıya sahiptir ve değişime çok daha dirençlidir. Çevrel inançlar ise merkezi inançlardan türetilmiştir. A ve B tipi inançlar, benliğin doğasıyla ilgili olduğundan diğer inançlara göre daha merkezidir. A tipi inançlar diğer insanlarla ortak bir fikir birliğini temele alırken, B tipi inançlar sıfır mutabakat içerir. Bu nedenle de A tipi inançlar daha merkezidir. Benzer 
şekilde C tipi inançlar da D tipi inançların türeticisi olduğundan daha merkezdedir. E tipi inançlar ise bu yapının en diş yörüngesindedirler; çünkü bu tür inançların diğer tip inançlarla ya çok zayıf bağları vardır ya da hiç ilişkileri yoktur. Çalışma kapsamında öğretmen adaylarının benlik saygılarını ve narsisizm düzeylerini belirleyen inançlar benlikleri hakkındaki inançlardan oluştuğundan A-B tipi inançlar olarak değerlendirilmiştir. Öğrenme- öğretmeye yönelik inançlar ise benlik saygısı, öz yeterlik, epistemolojik inançlar, alana özgü inançlar (matematik ya da bilimin doğası hakkındaki inançlar) gibi daha merkezi nitelikteki inançlardan etkilenerek şekillendiği için D-tipi inançlarla ilişkilendirilmiştir (Bahcivan ve Cobern, 2016). Aşağıdaki başlıklar bu inanç tipleri ile ilgili daha detaylı bilgiler verecektir.

\section{Benlik Saygis1}

Rosenberg (1965) benlik saygısını, kendini kabul etme ya da reddetmenin genel düzeyi olarak tarif etmekte; ayrıca, yüksek ve düşük benlik saygısı olmak üzere benlik saygısının iki yönünden bahsetmektedir. Benlik saygısı yüksek olan kişiler kendine güvenli, etkili iletişim kurabilen ve sağlam ilişkiler geliştirebilen kişiler oldukları için toplumsal anlamda da uyumludurlar (Gül, 2013). Bu kişiler dışadönüklük, açıklık ve zeka hakkında olumlu bir öz-bakışa sahiptirler (Campbell vd., 2002). Benlik saygısının geniş bir yelpazeye yayılan olumlu sosyal davranışlarla ve bireysel özelliklerle ilişkili olduğu genel olarak kabul gören bir düşüncedir (Baumeister vd., 2003; Bosson ve Swann, 2009). Ancak Baumesiter vd. (2003) yüksek öz saygılı bireylerin daha mutlu, başarısızlık karşısında daha dayanıklı, öz düzenleme becerilerini kullanmakta daha başarılı oldukları iddiasının literatürde yeterince desteklendiğini ifade etmekle beraber öz saygının literatürde bahsedilen diğer ilişkilerinin çok güçlü ve açık olmadığı konusunda eleştirel bir çalışma ortaya koymuşlardır. Onlara göre yüksek benlik saygısı, iyi niteliklerini dürüstçe ve içtenlikle onaylayan insanlarla birlikte, aynı zamanda narsistik, savunmacı ve kibirli bireyleri de kapsayan heterojen bir kategoridir. Bu durum ise benlik saygısının etkilerini ve ilişkilerini araştırmayı zorlaştırıyor görünmektedir. Ayrıca yapılan çoğu çalışmada öz saygının yukarıda sözü geçen bireysel özelliklerle az ya da çok ilişkili olduğu belirlense de bu ilişkinin yönü ve nedensellik durumu tam olarak ortaya konulmamıştır. Bütün bu eleştirilere rağmen sözü geçen özellikleriyle benlik saygısının, bireylerin hem özel hem de meslek yaşamında sergilediği davranış ve tutumları etkileyebilecek inançları barındırabileceği düşünülebilir. Bu araştırma kapsamında öz saygıyla birlikte narsisizm düzeyinin etkilerinin incelenmesi bahsi geçen karmaşıklığın giderilmesine de katkı sağlayacaktır.

\section{Narsisizm}

Freud (1914), narsisizm dış dünyadan çekilen libidonun (iç enerji) benliğe yöneltilmesiyle ortaya çıkan bir durum olarak açıklamaktadır. Freud'un kullandığı narsisizm terimi şu davranışsal olguları içermektedir: bireyin kendisine karşı olan öz-sevgi, kendi kendini beğenme, kendini büyütme gibi tutumlar, benlik saygısıyla ilişkili olan sevgi kaybı, başarısızlık gibi korkular, genel anlamda bir savunma eğilimi, mükemmeliyet için çabaya ve sevilme ihtiyacına yönelik motivasyon, başkalarıyla ilişkilere yön verecek nitelikte başkalarını kontrol etme, eleştiriye karşı hoşgörüsüzlük ve teşhircilik eğilimi (Raskin ve Terry 1988). 
Psikoloji literatürüne bakıldığında narsisizmin; patolojik ya da normal narsisizm olarak ele alındığı görülmektedir (Atay, 2009). Bununla birlikte böyle bir ayrıma gitmeksizin bireylerin "narsisizm" olarak adlandırılan bir özellikte farklılık gösterme derecesini ölçmeyi hedefleyen çalışmalar da yapılmıştır (Raskin ve Hall, 1979) Bu araştırma kapsamında da patolojik ya da normal ayrımına gitmeden narsisizm bir kişilik özelliği olarak ele alınmıştır. Narsisizmin temel özelliklerinden biri benliğin abartılı bir biçimde ön plana çıkarılıp diğer insanlara duyulan ilginin azalmasıdır (Timuroğlu ve İşcan, 2008). Narsist birey kendini olduğundan da önemli olarak algılar, aşırı beğenilme ve onaylanma ihtiyacı hisseder ve empati yapmakta yetersizdir (Kohut, 1977). Tüm bunlara rağmen literatürde narsisizmin olumlu sayılabilecek bazı etkilerinin bulunduğuna dair çalışmalar da göze çarpmaktadır. Örneğin narsistik kişilik yapılanması olan bireylerin motivasyonunun oldukça yüksek olması nedeniyle, liderlik rolünü hakkıyla üstlendikleri ve başarıyla yürüttükleri ifade edilmektedir (Atay, 2009). Ayrıca, narsist bireyler çevrelerinin kendilerine verdiği değeri artırma olanağı olan görevlerde daha iyi performans sergileyebilmekte (Wallace ve Baumeister, 2002) ve başarısızlık korkusu nedeniyle riskleri değerlendirmede ve önlem almakta oldukça başarılı olabilmektedir (Timuroğlu ve İşcan, 2008). Bunun yanında kendi benliklerine yönelik üstünlük algısı, onları en iyiye yönelmeye ve sadece en iyiyle ilişkili olmaya zorlayabilmektedir (Atay, 2010).

Narsisizmin temel boyutlarına göz atıldığında öğretmen adaylarının sınıf içi tercihlerini etkileyebilecek bazı kişilik özellikleri dikkati çekmektedir. Örneğin, otorite boyutu kapsamında, başkalarına bağımlı olmaktan aşırı düzeyde kaçınan narsist birey asıl otoritesi kabul edilmesi gerekenin kendisi olduğu yönünde bir inanç geliştirebilmekte ve bu durum baskın kişilik özelliğini besleyebilmektedir (Bogart, Benotsch ve Pavlovic, 2004). Narsisizmin diğer bir boyutu ise kendi üstün özelliklerine olan inancı ve bunu diğerlerine gösterme motivasyonunu ifade eden teşhirciliktir (Atay, 2010). Bu boyut narsisizm düzeyi yüksek olan bireyin bulunduğu ortamda kendini merkeze koyma çabasını sonuç verebilir. Diğer taraftan bireyin her isteğine çevresindekilerin rıza göstermesi beklentisini ifade eden hak iddia etme boyutu ise olaylara sadece kendi bakış açısından yaklaşmayı, empati yapmamayı, diğer insanların sadece onu onaylamak ve ona itaat etmek için var olduğu duygusunu taşımayı doğasında barındırmaktadır (Atay, 2010).

Öğrenme-Öğretme Anlayışı

Öğretme-öğrenme anlayışı, öğretmenlerin (ya da öğretmen adaylarının) öğrenme ve öğretmenin ne olduğu ve bu süreçlerin nasıl gerçekleşmesi gerektiğine dair inançlarının bütünüdür (Chan ve Elliott, 2004). Bu inançlar öğretmenlerin sınıf içi uygulamaları üzerinde önemli etkilere sahip olduğundan son yıllarda yapılan birçok araştırmaya konu olmuştur (Hewson ve Kerby, 1993; Koballa ve Graber; 2001; Güneş ve Bahçivan, 2018). Öğretmen adaylarının öğrenme anlayışlarını belirlemeye yönelik çalışmalara bakıldığında ezberleme, uygulama, bilginin artışı, anlama gibi sınıflandırmaların ortaya çıktığı görülmektedir (örn. Bahcivan, 2014b; Marton, Dall'Alba ve Beaty, 1993; Saljö, 1979; Tsai, 2004). Öğretmen ve öğretmen adaylarının öğretim yaklaşımlarının incelendiği araştırmalarda ise bilgi aktarımı, etkileşim, geleneksel, yapılandırmacı gibi kategoriler belirlenmiştir (örn, Koballa, Graber, Coleman ve 
Kemp, 2000; Tsai, 2002). Ayrıca bu araştırmalar öğretmen adaylarının öğrenme yaklaşımıyla öğretim yaklaşımının birbiriyle uyum içerisinde ve iç içe girmiş bir yapıda olduğunu da ortaya koymaktadır. Chan ve Elliott (2004) ise geliştirdikleri ölçek yardımıyla farklı sınıflandırmaları birleştirerek bireyin ögrenme-öğretme yaklaşımının yapılandırmacı ve geleneksel olarak kategorize edilebileceğini göstermiştir. Bu sınıflandırmaya göre, öğretimde öğrencinin merkeze alınması, öğrenmenin bireyselliği, aktif yaşantı ve deneyimler yolu ile keşfederek gerçekleşeceği yönündeki inançlar yapılandırmacı öğretme- öğrenme yaklaşımı kapsamında değerlendirilmektedir. Diğer taraftan öğretmen merkezli, öğrenmenin bilgi aktarma ve alma yoluyla, bolca alıştırma yaparak gerçekleşeceği yönündeki inançlar da geleneksel öğrenme-öğretme yaklaşımı kapsamında kabul edilmektedir. Geçmiş çalışmalar öğretme öğrenme yaklaşımlarının öğretmen adaylarının epistemolojik inançlarıyla, öğretim yeterliği inançlarıyla, pedegojik alan bilgileriyle ve öğretme davranışlarıyla ilişkili olduğunu göstermektedir (Bahçivan, 2014a; Bahcivan, 2014b; Koballa, Glynn, Upson ve Coleman, 2005).

\section{Araştırmanın Amacı ve Problem Cümlesi}

Araştırmada öğretmen adaylarının benlik saygıları, narsisizm düzeyleri ve öğretme-öğrenme yaklaşımları arasındaki ilişkiyi ortaya koymak amaçlanmıştır. Bu amaçla aşağıdaki araştırma problemine yanıt aranmaya çalışılmıştır: Öğretmen adaylarının benlik saygıları, narsisizm düzeyleri ve öğrenme-öğretme yaklaşımları arasındaki ilişkiler nelerdir?

\section{Önerilen Model ve Hipotezler}

Araştırma problemini irdelemek amacıyla Şekil 1'deki ilişkisel model önerilmiştir. Önerilen model öğretmen adaylarının öğretim inanç sistemlerinin bir bölümünü Rokeach'ın (1968) inanç sistemi yaklaşımına dayanarak aydınlatmayı amaçlamaktadır. Bu yaklaşıma göre merkezi inançlar çevrel inançların yapılarını etkilemektedir. Rokeach'a (1968) göre benlikle ilgili inançlar A ve B tipi merkezi inançlarken, daha merkezi inançlar tarafindan türetilen inançlar ise daha çevrel olan D tipi gibi inançlardır. Bu nedenle önerilen modelde yer alan benlik saygısı ve narsisizm düzeyi benlikle ilgili inançlardan oluştuğundan öğrenme-öğretme yaklaşımıyla ilgili inançlara göre daha merkezi biçimde konumlanırlar. Öte yandan birçok çalışmada benlik saygısı ve narsisizm arasında doğrudan bir bağlantı bulunmuştur (Campbell, Bosson, Goheen, Lakey ve Kernis, 2007) ve yüksek benlik saygısı narsisizmi de içeren heterojen bir yapıdadır (Baumeister vd., 2003). Bu nedenle bu modelde de benlik saygısının narsisizm düzeyi üzerinde pozitif yönlü bir etkiye sahip olduğu varsayılmıştır (Hipotez1). 


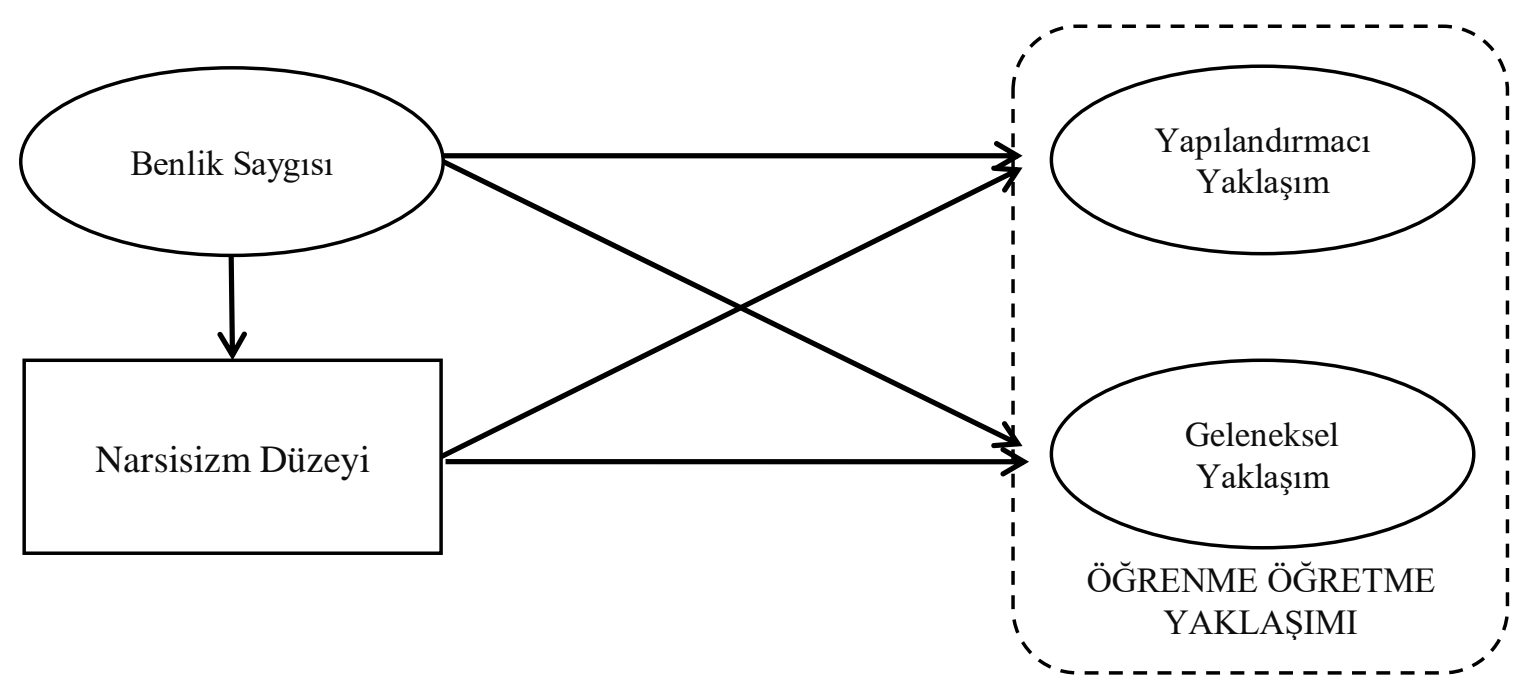

Şekil 1. Araştırma için önerilen model.

Benlik saygısı benlikle yakından ilişkili olduğundan Rokeach'ın (1968) yaklaşımına göre inanç sisteminde merkezi bir konumda yer alır. Ayrıca benlik saygısının, her ne kadar tamamı net olarak ortaya konulmuş olmasa da, bireyin yaşamının çeşitli yönleri üzerinde olumlu etkilere sahip olduğu bilinmektedir (Tennen ve Affleck, 1993; Baumeister vd., 2003). Örneğin yüksek benlik saygısı bireyi bir grup içinde konuşmak için ve grup yaklaşımıyla ilgili eleştiride bulunmak için daha istekli yapmakta ve yüksek benlik saygılı bireyler başarısızlık karşısında daha dayanıklı, öz düzenleme becerilerini kullanmakta daha başarılı olmaktadır (Baumeister vd., 2003). Bu gibi özellikler işbirlikli çalışma ortamlarına, yaşayarak ve deneyerek bilgiyi keşfetme süreçlerine daha sıcak bakmaya neden olabilir. Buradan hareketle araştırmada benlik saygısının yapılandırmacı yaklaşımı pozitif, geleneksel yaklaşımı negatif olarak yordayacağı varsayılmıştır (Hipotez 2). Yüksek düzeyde benlik saygısının heterojen yapısı içinde narsisizmin de bulunması benlik saygının etkilerini araştırmayı karmaşıklaştırmakta ve olumlu etkilerini sinırlamaktadır (Baumeister vd., 2003). Narsist bireyler anketlerde kendilerini benlik saygısı çok yüksek olacak şekilde ifade ederken, aslında benlik saygıları istikrarsız olan bireylerdir (Rhodewalt, Madrian ve Cheney, 1998). Bu nedenle özbildirim ölçeklerinde yüksek benlik saygısına sahipmiş gibi görünseler de uygulamada farklı davranışlar gösterebilmektedir (Atay, 2010; Baumeister vd., 2003). Örneğin narsist birey kişiler arası ilişkilerde önemli sorunlar yaşayabilmektedir (Campbell vd., 2002). Bu nedenle narsist bireyin işbirlikli çalışma ortamlarını gerektiren yaklaşımlara uzak olacağı düşünülebilir. Ayrıca narsisizmin otorite, teşhircilik ve hak iddia etme gibi boyutları bireyi bulunduğu topluluk içinde merkezde ve baskın olmaya yönlendirmekte, empati yapmasını engellemekte, çevresindekilerin ona itaat ve onu onaylamak için var olduğu duygusunu tetiklemektedir (Atay, 2010). Raskin ve Tery (1988) ise narsistik kişilik envanterinden yüksek puan alan bireyleri görece daha baskın ve benmerkezci olarak tanımlamaktadır. Bu özellikler sınıf ortamında öğretmen otoritesini ön plana çıkaran geleneksel yaklaşımla daha uyumlu görünmektedir. Bu düşünceyi destekleyen bir çalışmada Friedman (2016) narsisizmin öğretmen adaylarını öğrenci davranışlarını anlamaya çalışmaktansa, onları kendi karar ve yönlendirmelerine uymaya zorlayan bir kontrol yaklaşımına yönelttiğini belirlemiştir. 
Literatürdeki bu bilgilerden hareketle araştırmada narsisizm düzeyinin geleneksel öğrenme-öğretme yaklaşımını pozitif, yapılandırmacı öğrenme-öğretme yaklaşımını ise negatif olarak yordayacağı varsayılmıştır (Hipotez 3).

\section{YÖNTEM}

Örneklem

Çalışmaya 923 (702 kadın, 221 erkek) gönüllü öğretmen adayı katılmıştır. Öğretmen adayları Türkiye'de yer alan üç ayrı üniversiteden [Bolu Abant İzzet Baysal Üniversitesi (687), Kırşehir Ahi Evran Üniversitesi (180), Kırıkkale Üniversitesi (56)] seçilmiştir. Bazı sınırlılıkları bulunmasına rağmen istatiksel olarak anlamlı sonuçlar elde edebilmek için uygun örnekleme yöntemiyle farklı bölümlerden maksimum katılımcı sayısına ulaşılmaya çalışılmıştır (Creswell, 2008). Bu bağlamda örneklem 2017- 2018 bahar döneminde eğitim fakültesinde öğrenim görmekte olan, 143 fen bilgisi, 117 sosyal bilgiler, 141 bilgisayar ve öğretim teknolojileri, 99 Türkçe, 84 sınıf, 107 matematik, 123 okulöncesi ve 109 İngilizce öğretmeni adayından oluşmaktadır. Çalışmaya katılan öğretmen adaylarının 512'si 3. sınıfa 405'i 4.sınıfa devam etmektedir. 3 ve 4. sınıf öğretmen adayları, 1 ve 2 . sinıflara göre öğrenme-öğretme süreçleri konusunda daha fazla ders almış olması nedeniyle öğrenme- öğretmeye yönelik daha gelişmiş inançlara sahip olabilecekleri düşüncesiyle tercih edilmiştir. Bu tercihin öğretmen adaylarının öğretim inançları arasında anlamlı ilişkileri ortaya çıkarma olasılı̆̆ını artırması beklenmektedir.

\section{Veri Toplama Araçları}

Araştırmanın verileri üç ayrı ölçme aracı yardımıyla toplanmıştır: Rosenberg Benlik Saygısı Ölçeği (Rosenberg, 1965), Narsistik Kişilik Envanteri-16 (Ames, Rose ve Anderson, 2006) ve Öğrenme-Öğretme Yaklaşımı Ölçeği (Chan ve Elliott, 2004).

\section{Rosenberg Benlik Saygısı Ölçeği}

Rosenberg Benlik Saygısı Ölçeği ([RBSÖ]; Rosenberg, 1965), bir kişinin insan olarak değerliliğinin genel bir değerlendirmesi olarak anlaşılan küresel benlik saygısını ölçmek için dünya genelinde yaygın olarak kullanılan, geçerli ve güvenilir veri ve çıkarımların elde edilmesini sağlayan bir ölçüm aracıdır (Crandall, 1973; Rosenberg, 1979). Beş olumlu ve beş olumsuz ifadenin yer aldığı on maddelik ölçek, "Bazen kesinlikle bir işe yaramadığımı düşünüyorum”, "Genel olarak kendimden memnunum.” gibi ifadeleri içermektedir. Katılımcıların her madde için kararlarını 1 (kesinlikle katılmıyorum) - 5 (kesinlikle katılıyorum) aralığında işaretlemeleri beklenmektedir. Bu çalışmada ölçekte yer alan olumsuz maddeler ters puanlanarak ölçekten alınan yüksek puanların yüksek benlik saygısını göstermesi sağlanmıştır.

RBSÖ’nün Türkçe' ye uyarlama çalışması Çuhadaroğlu (1986) tarafindan .70 üzerinde güvenirlik düzeyiyle gerçekleştirilmiştir. $\mathrm{Bu}$ çalışma bağlamında öncelikle doğrulayıcı faktör analizi gerçekleştirilmiş ve faktör yükü .30'un altında olduğu belirlenen 8 . madde çıkarıldıktan sonra tüm 
maddelerin tek boyut altında toplandığı görülmüştür ( $\chi 2$ / df=4.82; TLI= .95; CFI= .98; RMSEA= .064). Diğer maddelerin faktör yüklerine bakıldığında .47 (madde 2) ve .79 (madde 10) arasında değiştiği görülmüştür. Güvenirlik analizi sonucu Cronbach Alpha değeri .85 olarak hesaplanmıştır.

\section{Narsistik Kişilik Envanteri-16}

Narsistik kişilik envanteri (NKE) ilk olarak Raskin ve Hall (1979) tarafından, bir kişilik bozukluğu olarak narsisizmi ölçmekten çok bir kişilik özelliği olarak narsisizmdeki bireysel farkl1lıkları belirlemek amacıyla geliştirilmiştir. Sonrasında gerçekleştirilen yeniden düzenleme çalışmaları (Emmons, 1987; Raskin ve Terry, 1988) sonucu 40 sorudan oluşan ve 7 faktörlü (otorite, üstünlük, hak iddia etme, sömürücülük, teşhircilik, kendine yeterlik, kendini beğenme) NKE-40 formuna ulaşılmıştır. 2000'li yıllara kadar bu şekliyle yaygın olarak kullanılan NKE-40, Ames, Rose, ve Anderson (2006) tarafından zaman kaybını engellemek ve kullanıcı hatalarını minimize etmek amaciyla yeniden düzenlenerek 16 maddelik NKE-16 elde edilmiştir. Ames vd. (2006) 5 ayrı araştırma yardımıyla ölçeğin ortalama iç güvenirliğini .67 olarak belirlemişler, ayrıca "kendini beğenme” boyutu dışında NKE-16'nın Raskin ve Terry (1988) tarafindan geliştirilen NKE-40 ile yüksek korelasyon gösterdiğini tespit etmişlerdir. NKE-16 her ne kadar NKE-40'ın içerdiği yedi faktörden altısını içeren maddelerden oluşsa da tek boyutlu bir ölçek olarak geliştirilmiştir.

NKE-16'nın Türkçe'ye uyarlaması Atay (2009) tarafından gerçekleştirilmiş ve 16 maddelik ölçek için Cronbach Alpha değeri .62 olarak belirlenmiştir. Bu çalışma kapsamında ise gerçekleştirilen güvenirlik analizi sonucu Cronbach Alpha korelasyon katsayısı .67 olarak elde edilmiştir. Yapılan analizler ve literatürde NKE-16'nın kullanıldığı diğer araştırmalar (örn. Temel, 2008) göz önüne alınarak bu çalışmada gerçekleştirilen çıkarımsal istatistiklerde öğretmen adaylarının ölçekten aldıkları toplam narsisizm puanlarının kullanılmasına karar verilmiştir. NKE-16'nın her maddesi narsistik ve narsistik olmayan iki ifade (örn. "Ben de herkes gibi biriyim" - "Sıra dışı bir insanım”) içermekte ve katılımcının bu ifadelerden kendine en yakın olanı seçmesi istenmektedir. Puanlanma yapılırken narsistik ifadelere 1 puan, narsistik olmayan ifadelere 0 puan verilmekte ve 0-16 aras bir puan elde edilmektedir. Bu şekilde, ölçekten elde edilen puanın yüksekliği narsisizm düzeyinin yüksekliğine işaret etmektedir.

\section{Öğrenme-Ö̆̆retme Yaklaşımı Ölçĕ̆i}

Öğrenme-öğretme yaklaşımı ölçeği (ÖÖYÖ), Chan ve Elliott (2004) tarafından öğretmen adaylarının öğretme ve öğrenme anlayışlarını belirlemek amacıyla geliştirilmiş ve geçerlik çalışmaları yapılmıştır. ÖÖYÖ yapılandırmacı yaklaşım ve geleneksel yaklaşım olmak üzere iki faktör içermektedir. Ölçeği geliştiren araştırmacılara göre yapılandırmacı yaklaşımda öğrenme, öğrenen tarafından akıl yürütme ve gerekçelendirme yoluyla bilginin oluşturulması, öğretim ise öğrenme sürecinin hazırlanması ve kolaylaştırılması olarak görülmektedir. Geleneksel yaklaşımda ise öğrenme çoğunlukla ezberlemeyi ve alıştırma yapmayı temel alan pasif bir süreç olarak, öğretim ise bilginin öğretmenden öğrenciye doğrudan transferi olarak kabul edilir (Chan ve Elliott, 2004). Ölçekte yapılandırmacı anlayışı 12 madde (örn. "Etkili öğretim, öğrencileri daha fazla tartışmaya ve yaparak- 
yaşayarak öğrenmeye teşvik eder”, “Öğrencilere fikirlerini ifade edebilmeleri için fırsatlar verilmelidir"), geleneksel anlayışı 18 madde (örn. "Bir öğretmenin başlıca rolü öğrencilere bilgi aktarmaktır”, “Öğrenme, her şeyden önce alıştırma ve uygulamayla gerçekleşir”) temsil etmektedir. Maddeleri 5'li Likert ölçeği şeklinde düzenlenen ölçekte ( 1 = kesinlikle katılmıyorum, 5 = kesinlikle katılıyorum) öğretmen adayının yapılandırmacı maddelerden yüksek puan alması yapılandırmacı yaklaşımı benimsediğini göstermektedir.

ÖÖYÖ ilk olarak Eren (2009) tarafindan, iyi bir model uyumu ( $\chi 2 / \mathrm{df}=2.42$; NNFI= .93; $\mathrm{CFI}=.94 ; \mathrm{RMSEA}=.06$ ) ve yüksek güvenirlik düzeyi ile (yapılandırmacı boyut için $\alpha=.92$, geleneksel boyut için $\alpha=.89$ ) Türkçe' ye uyarlanmıştır. Bu çalışmada ise geçerlik için 30 madde üzerinde doğrulayıcı faktör analizi ( $\mathrm{n}=923$ ) yapılmıştır. Bu kapsamda öncelikle faktör yükleri .30'un altındaki 9,11,15 ve 30. maddeler çıkarıldıktan sonra ÖÖYÖ’nın geleneksel yaklaşım (14 madde) ve yapılandırmacı yaklaşım (12 madde) olmak üzere iki faktörden oluştuğu doğrulanmıştır. Uyum indislerine bakıldığında verilerin kabul edilebilir bir model uyumuna işaret ettiği belirlenmiştir $(\chi 2 / \mathrm{df}=3.83$; TLI $=.89 ; \mathrm{CFI}=.903$; RMSEA $=.05)$. Yapılandırmacı yaklaşım boyutu için güvenirlik düzeyi .90 , geleneksel yaklaşım boyutu için .86 olarak gözlenmiştir.

\section{Veri Toplama İşlemi}

Araştırmada kullanılan tüm ölçme araçları dört bölümden oluşan tek bir formda birleştirilerek uygulanmıştır. İlk bölümde, öğretmen adaylarından cinsiyet, bölüm, sınıf düzeyi gibi bazı demografik bilgileri doldurmaları istenmiştir. Sonraki bölümlerde ise sırasıyla ÖÖYÖ, RBSÖ ve NKE-16 yer almıştır. Veri toplanma işlemi öncesinde Bolu Abant İzzet Baysal Üniversitesi Etik Komitesi’nin onayı alınmıştır. Veri toplama aracı normal ders süreleri içinde öğretmen adaylarına dağıtılmış, çalışmanın amacı hakkında yapılan bilgilendirmenin ardından gönüllü olanlardan soruları cevaplamaları istenmiştir. Veri toplama işlemi sırasında herhangi bir zaman sınırlaması uygulanmamış, ortalama yanıt verme süresinin yaklaşık 20 dakika olduğu gözlenmiştir. Veri toplama işlemi bittikten sonra, elde edilen veriler SPSS ortamına aktarılmıştır.

\section{Verilerin Analizi}

Veriler üzerinde betimsel ve çıkarımsal istatistikler yapılmıştır. SPSS kullanılarak ortalama ve standart sapma gibi betimsel sonuçlar yanında geçerlik ve güvenirlik sonuçları elde edilmiştir. Geçerliliği kontrol etmek amacıyla AMOS kullanılarak doğrulayıcı faktör analizi yapılmıştır. Son olarak öğretmen adaylarının benlik saygıları, narsisizm düzeyleri ve öğrenme-öğretme yaklaşımları arasındaki ilişkileri incelemek amacıyla AMOS aracıllğıyla bir yapısal eşitlik modeli analizi gerçekleştirilmiştir.

\section{BULGULAR}

Öğretmen Adaylarının Benlik saygıları, Narsisizm Düzeyleri ve Öğrenme Öğretme Yaklaşımlarıyla ilgili betimsel bulgular aşağıda verilmiştir. 
Tablo 1'de sunulan ortalama puanlara bakıldığında tüm maddelerin orta nokta olan 2.5 üzerinde ortalamaya sahip olduğu görülmektedir. Buradan hareketle öğretmen adaylarının genel olarak yüksek benlik saygısına sahip olduğu ifade edilebilir. Yüksek ortalamaya sahip maddelere bakıldığında öğretmen adaylarının "kendilerinin bazı olumlu özellikleri olduğuna" ve "diğer insanların birçoğunun yapabildiği kadar bir şeyler yapabileceğine" inandıkları söylenebilir. Ayrıca ters puanlama yapılan maddelerin ortalamalarının diğerlerine kıyasla düşük olduğu görülmektedir. Düşük benlik saygısını gösterir ifadelerinin yer aldığı bu maddelerden en düşük ortalamaya sahip olanlara bakıldığında "bazen kendilerinin hiç de yeterli bir insan olmadığını düşündükleri” ve "kendilerinde gurur duyacak fazla bir şey bulamadıkları" şeklindeki ifadelerden oluştukları görülmektedir. Öğretmen adaylarının ölçekte yer alan bu gibi olumsuz ifadelere katılmama derecelerinin olumlu ifade içeren maddelere katılma derecelerine göre kısmen düşük olduğu anlaşılmaktadır. Bunun yanında Tablo 1'de yüksek benlik saygısı ifade eden maddelere ait standart sapma değerlerinin düşük benlik saygısı ifade edenlerden daha küçük olduğu görülmektedir. Buradan yola çıkarak öğretmen adaylarının benlikleriyle ilgili olumlu düşünceler konusunda olumsuzlara kıyasla daha yakın inançlara sahip oldukları sonucuna varılabilir.

Tablo 1. Benlik saygısı ölçeğine ait betimsel bulgular.

\begin{tabular}{ccc}
\hline Madde $^{*}$ & $\overline{\mathbf{x}}$ & Ss \\
\hline B1 & 3,97 & 0,90 \\
B2 & 3,08 & 1,20 \\
B3 & 4,27 & 0,78 \\
B4 & 4,31 & 0,82 \\
B5 & 3,79 & 1,11 \\
B6 & 3,92 & 1,17 \\
B7 & 4,17 & 0,96 \\
B9 & 3,80 & 1,20 \\
B10 & 4,02 & 0,98 \\
\hline
\end{tabular}

${ }^{*}$ Koyu olarak temsil edilen maddeler yeniden kodlanmıştır.

Öğretmen adaylarının NKE-16'da yer alan maddelerden aldıkları narsisizm düzeyini ifade eden toplam puanların ortalamasının 5.25 olduğu görülmektedir (Tablo 2). Alınabilecek en yüksek puanın 16 olması nedeniyle genel anlamda öğretmen adaylarının narsisizm düzeylerinin orta düzeyin altında olduğu söylenebilir. Maddelere ait ortalama puanlara bakıldığında narsistik ifadelerin daha çok tercih edildiği iki madde (n1, n7) olduğu görülmektedir. Bu maddeler göz önüne alınırsa öğretmen adaylarının yarıdan çoğunun "ilgi merkezi olmaktan gerçekten hoşlandıklarına" ve "insanları istediği her şeye inandırabilecekleri” kanaatinde oldukları söylenebilir. Bunun yanında .47 ortalama puanla öğretmen adaylarının yarıya yakın kısmının narsist ifade seçeneğini işaretlediği 5. madde, bu öğretmen adaylarının insanlar üzerinde otorite sahibi olmaktan hoşlandıklarına işaret etmektedir. Narsist ifadelerin en az tercih edildiği 8. ve 16. madde bağlamında öğretmen adaylarının çoğunlukla insanlardan çok şey beklemek 
yerine başkaları için bir şeyler yapmaktan hoşlandığı ve diğer insanlara göre daha kabiliyetli olduğuna değil başka insanlardan öğrenebileceği çok şey bulunduğuna inandıkları söylenebilir.

Tablo 2. Öğretmen adaylarının narsisizm düzeylerine ilişkin betimsel bulgular.

\begin{tabular}{ccc}
\hline Kod $^{*}$ & $\overline{\mathbf{x}}$ & Ss \\
\hline $\mathrm{n} 1$ & .59 & 0,49 \\
$\mathrm{n} 2$ & .39 & 0,49 \\
$\mathrm{n} 3$ & .19 & 0,39 \\
$\mathrm{n} 4$ & .24 & 0,43 \\
$\mathrm{n} 5$ & .47 & 0,50 \\
$\mathrm{n} 6$ & .20 & 0,40 \\
$\mathrm{n} 7$ & .60 & 0,49 \\
$\mathrm{n} 8$ & .15 & 0,36 \\
$\mathrm{n} 9$ & .42 & 0,49 \\
$\mathrm{n} 10$ & .29 & 0,45 \\
$\mathrm{n} 11$ & .43 & 0,50 \\
$\mathrm{n} 12$ & .20 & 0,40 \\
$\mathrm{n} 13$ & .29 & 0,46 \\
$\mathrm{n} 14$ & .40 & 0,49 \\
$\mathrm{n} 15$ & .17 & 0,38 \\
$\mathrm{n} 16$ & .16 & 0,37 \\
$\mathrm{~T}$ & 5.25 & 2.93 \\
\hline
\end{tabular}

*NKE-16'nın maddeleri "n" ile, ölçekten alınan toplam puan ise "T" ile temsil edilmiştir.

Öğretmen adaylarının ÖÖYÖ' ne verdiği yanıtlardan elde edilen puanların ortalamalarına bakıldığında (Tablo 3) yapılandırmacı yaklaşımı temsil eden maddelerin daha yüksek ortalamaya sahip olduğu görülmektedir. Ortalama puanı yüksek olan maddeler göz önüne alınarak öğretmen adaylarının, öğrencilerin duygu, düşünce ve özel gereksinimlerinin dikkate alınması ve onların tartışarak, etkinliklere katılarak kendi yaşantıları aracıllğıyla kendi bilgilerini oluşturmaya teşvik edilmeleri gerektiğine inandıkları söylenebilir. Öte yandan geleneksel yaklaşımı temsil eden maddelerden 6 tanesine ait ortalamaların 2.5 üzerinde olduğu görülmektedir (G26, G7, G29, G20, G4, G23). Bu maddelere dikkat edildiğinde öğretmen adaylarının, bir öğretmenin öğrencileri üzerindeki kontrolünün ve sınıftaki otoritesinin öğrenme için önemli olduğuna inandıkları ifade edilebilir. Ayrıca öğretmen adaylarının, öğretmenin bilgi aktarımı görevinin önemli olduğuna ve öğrenmenin çoğunlukla bilgi almak yoluyla gerçekleşeceğine, bunun yanında öğrencinin hatalarına beklemeden müdahale edilmesinin gerekliliğine inandığı düşünülebilir. Yapılandırmacı yaklaşım boyutundaki maddelere ait standart sapma değerlerinin geleneksel boyutla kıyaslandığında daha düşük olması, öğretmen adaylarının yapılandırmacı yaklaşımda geleneksel yaklaşıma kıyasla daha yakın düşünce yapısına sahip olmaları şeklinde yorumlanabilir. 
Tablo 3. Öğrenme-öğretme yaklaşımı ölçeği (ÖÖYÖ)'ne ait betimsel bulgular

\begin{tabular}{|c|c|c|}
\hline Madde $^{*}$ & $\overline{\mathbf{x}}$ & SS \\
\hline Y1 & 4,68 & 0,73 \\
\hline Y2 & 4,57 & 0,74 \\
\hline Y5 & 4,40 & 0,79 \\
\hline Y6 & 4,45 & 0,83 \\
\hline Y10 & 4,58 & 0,76 \\
\hline Y13 & 4,58 & 0,82 \\
\hline Y14 & 4,49 & 0,82 \\
\hline Y18 & 4,12 & 0,84 \\
\hline Y19 & 4,19 & 0,82 \\
\hline Y24 & 4,20 & 0,86 \\
\hline Y25 & 4,56 & 0,79 \\
\hline Y28 & 4,27 & 0,91 \\
\hline G3 & 2,09 & 1,09 \\
\hline G4 & 2,56 & 1,06 \\
\hline G7 & 3,10 & 1,13 \\
\hline G8 & 1,96 & 1,08 \\
\hline G12 & 2,06 & 1,19 \\
\hline G16 & 2,47 & 1,18 \\
\hline G17 & 2,08 & 1,10 \\
\hline G20 & 2,69 & 1,16 \\
\hline G21 & 1,92 & 1,03 \\
\hline G22 & 2,47 & 1,26 \\
\hline $\mathrm{G} 23$ & 2,55 & 1,28 \\
\hline G26 & 3,19 & 1,14 \\
\hline G27 & 2,06 & 1,16 \\
\hline G29 & 2,97 & 1,18 \\
\hline
\end{tabular}

Öğretmen Adaylarının Benlik Saygıları, Narsisizm Düzeyleri ve Öğrenme-Öğretme Yaklaşımları Arasındaki İlişki

Öğretmen adaylarının benlik saygıları, narsisizm düzeyleri ve öğrenme-öğretme yaklaşımları arasındaki ilişki yapısal eşitlik modellemesi analizi ile incelenmiştir. Ortaya çıkan anlamlı yapısal ilişki Şekil 2'de sunulmuştur. Analiz sonucu modelin kabul edilebilir bir uyum gösterdiği belirlenmiştir $(\chi 2 / \mathrm{df}=3.34, \mathrm{CFI}=0.88, \mathrm{TLI}=0.87$ ve RMSEA $=0.05)$. Model yapılandırmacı yaklaşım ve geleneksel yaklaşımdaki varyansın sırasıyla $\% 21$ ve \%7'sini, narsisizm düzeyindeki varyansın da $\% 6$ 'sını açıklamaktadır. 


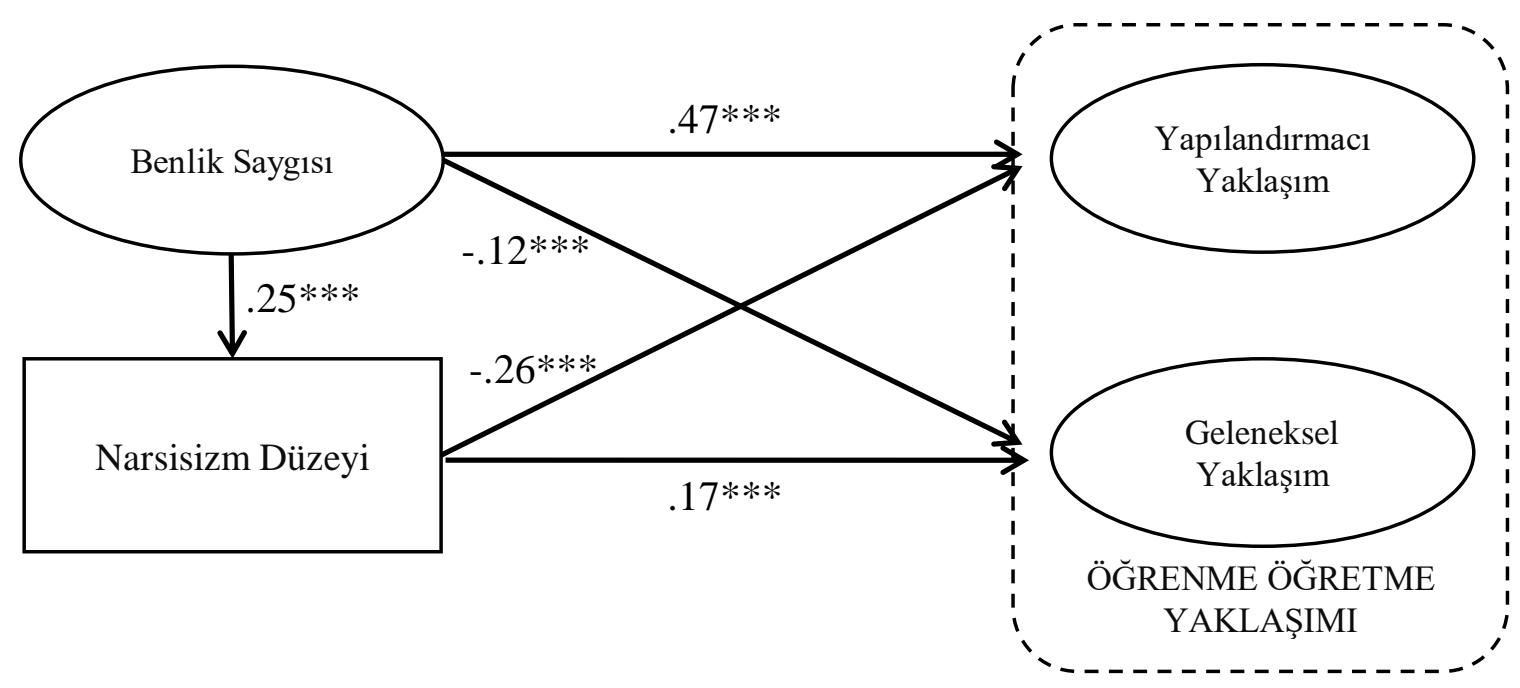

Şekil 2. Önerilen modelde gözlenen ilişkiler $(* * *<0,001)$.

Şekil 2, öğretmen adaylarının benlik saygıları ve narsisizm düzeyleri arasındaki ilişki hakkında öne sürülen hipotezin gözlemlendiğini ortaya koymaktadır. Yani öğretmen adaylarının benlik saygıları narsisizm düzeylerini pozitif yönde yordamaktadır. Öğretmen adaylarının narsisizm düzeyleri ve benlik saygılarının öğrenme-öğretme yaklaşımları ile ilişkisi hakkındaki hipotezlerin de sağlandığı anlaşılmaktadır. Şekil 2'de görüldüğü gibi narsisizm düzeyi geleneksel yaklaşımı pozitif yönde yordarken, yapılandırmacı yaklaşımı negatif olarak yordamaktadır. Benlik saygısı ise geleneksel yaklaşımı negatif, yapılandırmacı yaklaşımı pozitif olarak yordamaktadır.

\section{TARTIŞMA, SONUÇ VE ÖNERILLER}

Çalışmada öğretmen adaylarının benlik saygıları, narsisizm düzeyleri ve öğrenme-öğretme yaklaşımları arasındaki yapısal ilişkiyi incelemek amaçlanmıştır. Bu amaçla Rokeach'in (1968) inanç sistemi teorik çerçeve olarak kullanılmıştır. Bu bağlamda araştırmanın değişkenleri literatüre dayanarak birer inanç tipi olarak tanımlanmış, benlik saygısı ve narsisizm düzeyini gösteren inançların daha merkezi, öğrenme-öğretme yaklaşımının ise çevrel konumda yer aldığı modelin bir parçası olarak incelenmiştir.

Benlik saygısı ve narsisizm arasında bir ilişki bulunduğu daha önce birçok araştırma ile ortaya konmuştur (Atay, 2010; Pilch ve Hyla, 2017). Benlik saygısı yüksek olan bireylerden bazılarının narsist olduğu ancak hemen hemen hiçbir narsistin benlik saygısının düşük olmadığı bilinmektedir (Baumeister vd., 2003). Ancak her ne kadar ampirik araştırmalar narsistik kişilik hakkındaki çalışmalarda benlik saygısının önemini doğrulasa da benlik saygısı ve narsisizm arasındaki ilişki hakkındaki çalışma sonuçları yetersiz veya çelişkili bulgular ortaya koymaktadır (Pilch ve Hyla, 2017). Bu araştırma kapsamında elde edilen benlik saygısının narsisizm düzeyini pozitif olarak yordadığı bulgusunun bu anlamda literatüre katkı sağladığı ifade edilebilir. 
Araştırmada benlik saygısının öğretmen adaylarının öğrenme-öğretme yaklaşımlarıyla ilişkili olduğu görülmüştür. Benlik saygısı yapılandırmacı yaklaşımı pozitif, geleneksel yaklaşımı negatif olarak yordamaktadır. Benlik saygısı yüksek olan bireylerin etkili iletişim kurabilen ve sağlam ilişkiler geliştirebilen kişiler oluşu (Gül, 2013), grup içinde konuşmak ve grup yaklaşımıyla ilgili eleştiride bulunmak için daha istekli, başarısızlık karşısında daha dayanıklı, öz düzenleme becerilerini kullanmakta daha başarılı olmaları (Baumeister vd., 2003) gibi geçmiş çalışmalara ait bazı bulguların benlik saygısıyla yapılandırmacı yaklaşım arasındaki pozitif ilişkinin nedenlerinden bazıları olduğu düşünülebilir. Bu özelliklere sahip öğretmen adaylarının karşılaşılabilecek bazı olumsuzlukları göze alarak, tartışarak bilginin üretildiği grup çalışmalarına, öğrencilerin bilgiyi kendilerinin oluşturma sürecini yaşayacakları etkinliklere daha fazla önem verecekleri varsayılabilir. Öte yandan Rosenberg'in (1968) bir kişinin insan olarak değerliliğinin genel bir değerlendirmesi olarak tarif ettiği benlik saygıs1 yüksek olan bir öğretmen adayının, bir insan olarak kendinin değerliliğinin farkında olduğu düşünülebilir. Buradan hareketle narsist olmamak kaydıyla bu öğretmen adayının öğrencilerine de aynı perspektiften bakarak, onları bir birey olarak önemseyeceği ve onları anlamaya çaba göstereceği söylenebilir.

Narsist bireylerin benlik saygılarının da yüksek olduğu ve bu durumun benlik saygısının çeşitli değişkenlerle olan ilişkilerini araştırmayı zorlaştırdığı bilinmektedir (Baumeister vd., 2003) Ancak narsist bireyler davranışları ve diğer insanlarla ilişkileri bakımından narsist olmayan ve benlik saygısı yüksek olan bireylerden farklılaşmaktadır. Örneğin narsist birey kişiler arası ilişkilerde daha başarısız olma, topluluk içinde baskın ve benmerkezci davranma, empati yapamama, çevresinden itaat ve onay bekleme gibi özelliklere sahiptir (Atay, 2010; Campbell vd., 2002; Raskin ve Tery, 1988). Geçmiş çalışmalardaki bu bulgulardan hareketle bu çalışmada benlik saygısının aksine narsisizm düzeyinin yapılandırmacı yaklaşımla negatif, geleneksel yaklaşımla pozitif yönlü bir ilişkiye sahip olacağı tahmin edilmiş ve bu tahmin doğrulanmıştır. Yukarıda söz edilen narsist kişilik özelliklerinin narsisizm düzeyi yüksek olan öğretmen adaylarını geleneksel yaklaşıma daha fazla eğilim göstermelerine yol açmış olabilir. Öğretmen adaylarının narsistik arzularının sınıf davranışı tercihlerindeki etkilerini inceleyen Friedman (2016), narsisizm düzeyi yüksek öğretmen adaylarının sınıfta kullanma eğiliminde oldukları kontrol yaklaşımının farklılaştığını belirlemiştir. Güçlü narsistik arzulara sahip öğretmen adayları öğrencinin bir birey olarak önemini ve onların ihtiyaçlarının karşılandığı bir sınıf ortamının gerekliliğini ve öğrencilerin davranışlarını anlamayı önemseyen kontrol yaklaşımını benimsememektedir. Aksine, sınıfta zorlayıcı bir disiplin uygulama, kendi öğretim yaklaşımı ve başarı kriterleri için zorlama, öğrencilerin öğretmenlerinin kararlarını ve düşüncelerini inkâr edilemez bir biçimde kabul etmelerini zorunlu kılma gibi öğretmen merkezli bir sınıf kontrolü yaklaşımını benimsemektedir. Bu çalışmanın bulguları da öğretmen yetiştirme alanında narsisizmle ilgili nadir çalışmalardan biri olan Friedman'ın (2016) çalışmasında ulaştığı sonucu desteklemekle birlikte daha genel olarak narsisizm düzeyi yüksek öğretmen adaylarının geleneksel öğrenme-öğretme yaklaşımına daha yatkın olduklarını ortaya koymaktadır. Öğretmen yetiştirme alanında öğretmen adaylarının benlikleriyle ilişkili inançlarının, 
narsisizm ve benlik saygısı gibi psikolojik boyutların öğrenme-öğretme yaklaşımlarıyla ilişkilerinin incelendiği çalışmaların azlığı dikkate alındığında araştırmanın sonuçlarının alana önemli katkılar sunduğu düşünülebilir.

Genel olarak bakıldığında çalışmada elde edilen bulgular Rokeach'ın (1968) iddialarını destekler niteliktedir. Rokeach'a göre merkezi inançlar daha çevrel olan inançlarla daha fazla ilişkiye sahiptir ve onları etkiler. Çalışmada da benlikle ilişkili merkezi inançlar olan benlik saygısı ve narsisizmin daha çevrel bir inanç olan öğrenme ve öğretme hakkındaki inançlar üzerinde etkili oldukları görülmüştür.

Son yıllarda eğitim dünyasında yapılandırmacı yaklaşıma yapılan vurguya, öğretmen yetiştirme programlarında bu yaklaşımı yaygınlaştırmak için gösterilen çabalara rağmen bu yaklaşım öğretmenlerin sınıf ortamındaki uygulamalarına gerektiği ölçüde yansımamaktadır (Airasian ve Walsh, 1997; Brooks ve Brooks, 1999; Doruk, 2014; Windschitl, 2002). Araştırmalar, öğretmenlerin sınıftaki uygulamalarının ve öğretimle ilgili kararlarının onların öğrenme ve öğretmeyle ilgili inançlarıyla güçlü bir ilişkiye sahip olduğunu göstermektedir (Pajares, 1992). Bu araştırmada ise öğretmen adaylarının kendi benlikleriyle ilgili inançlarından bazılarının (benlik saygısı ve narsisizm) öğrenme-öğretme hakkındaki inançları üzerinde etkili olduğuna dikkat çekilmiştir. Öte yandan günümüz dünyasında narsisizm giderek yaygınlaşmakta ve bu durum toplumlar için önemli sonuçlar doğurmaktadır (Lasch, 1979; Timuroğlu ve İşcan, 2008; Twenge ve Campbell, 2009) ve araştırmamızda görüldüğü gibi narsisizm, öğretmen adaylarında geleneksel öğrenme-öğretme yaklaşımını tetikliyor görünmektedir. O halde sınıf ortamında yapılandırmacı uygulamalara geçişi engelleyen etkenlerden biri de bazı öğretmen adayları (ya da öğretmenlerin) narsisizm düzeylerinin yüksekliği olabilir. Buradan hareketle öğretmen yetiştirme alanındaki araştırmalarda öğretmen adaylarının farklı psikolojik yönlerinin ve inançlarının ögretim inanç sistemindeki yerlerinin daha fazla irdelenmesinin alana katkı sağlayacağı ifade edilebilir. Öğretmen mesleğine yapılacak yönlendirmelerde de benlik saygısı yüksek, narsisizm düzeyi düşük bireylerin geleneksel öğrenme-öğretme yaklaşımından çok yapılandırmacı yaklaşıma eğilimli olmaları göz önünde bulundurulabilir.

Araştırmada verilerin özbildirim yolu ile toplanması bir sınırlılık olarak düşünülebilir. Özellikle narsisizm düzeyi yüksek bireylerin benlik saygılarıyla ilgili ifadelerde kendi benlik saygılarını yüksek tutmaya yönelik seçimler yapmaları beklenebilir. Bu durum yüksek benlik saygısına sahip bireylerin içerisinde narsisizm düzeyi yüksek olanların da karışmasıyla benlik saygısının etkilerini araştırmayı karmaşıklaştırmaktadır. Ancak araştırmada narsisizm düzeyi yüksek öğretmen adaylarının öğrenmeöğretme yaklaşımı ölçeğine verdikleri yanıtlarla benlik saygısı yüksek olanlardan ayrıştıkları görülmüştür. Benlik saygısının yüksek olması yapılandırmacı yaklaşıma yönelmeyi tetiklerken narsisizm düzeyinin yüksek oluşu geleneksel yaklaşıma yönelmeyi tetiklemektedir.

Araştırma kapsamında belirlenen benlik saygısı ve narsisizm düzeyinin öğrenme-öğretme yaklaşımları üzerindeki etkisinin akademik başarı, cinsiyet vb. farklı değişkenlere göre değişiminin incelenmesi gelecek çalışmalar için önemli araştırma konuları olabilir. Ayrıca, ilerleyen çalışmalarda benlik saygısı ve narsisizm dışında merkezi nitelikteki farklı inançlarla ilişkili olan çeşitli psikolojik 
özelliklerin öğretmen adaylarının öğrenme-öğretmeye dair inançlarıyla ve sınıf uygulamalarıyla ilişkisi araştırılabilir.

\section{KAYNAKÇA}

Airasian, P. W. ve Walsh, M. E. (1997). Constructivist cautions. Phi Delta Kappan, 78 (6), 444-449.

Ames, D. R., Rose, P. ve Anderson, C. P. (2006). The NPI-16 as a short measure of narcissism. Journal of Research in Personality, 40, 440-450.

Atay, S. (2009). Narsistik kişilik envanterinin Türkçe'ye standardizasyonu. İktisadi ve İdari Bilimler Fakültesi Dergisi, 11 (1), 1-16.

Atay, S. (2010). Çalışan Narsist. İstanbul: Namar Yayınları

Bahcivan, E. ve Cobern, W. W. (2016). Investigating coherence among Turkish elementary science teachers' teaching belief systems, pedagogical content knowledge and practice. Australian Journal of Teacher Education, 41 (10), 63.

Bahçivan, E. (2014a). Examining relationships among Turkish pre-service science teachers' conceptions of teaching and learning, scientific epistemological beliefs and science teaching efficacy beliefs. Journal of Baltic Science Education, 13 (6), 870-882.

Bahçivan, E. (2014b). Investigating coherence between preservice science teachers' conceptions of learning and teaching science: a phenomeno-graphic study. Ahi Evran Üniversitesi Kırşehir Eğitim Fakültesi Dergisi, 15 (3), 147-166.

Baumeister, R.F., Campbell, J.D., Krueger, J.I. ve Vohs, K.D. (2003). Does high self-esteem cause better performance, interpersonal success, happiness, or healthier lifestyles? Psychological Science in the Public Interest, 4, 1-44.

Bogart, L. M., Benotsch, E. G. ve Pavlovic, J. D. P. (2004). Feeling superior but threatened: The relation of narcissism to social comparison. Basic and applied social psychology, 26 (1), 35-44.

Bosson, J. ve Swann, W.B., Jr. (2009). Self-esteem: Nature, origins, and consequences. In R.

Brooks, J. G. ve Brooks, G. M. (1999). In search of understanding: The case for constructivist classrooms. Alexandria, VA: Association for Supervision and Curriculum Development.

Campbell, W. K., Rudich, E. A. ve Sedikides, C. (2002). Narcissism, self-esteem, and the positivity of self-views: Two portraits of self-love. Personality and Social Psychology Bulletin, 28 (3), 358368.

Campbell, W.K., Bosson, J.K., Goheen, T.W., Lakey, C.E. ve Kernis, M.H. (2007). Do narcissists dislike themselves "deep down inside"? Psychological Science, 18, 227-229.

Chan, K. W. and Elliott, R. G. (2004). Relational analysis of personal epis-temology and conceptions about teaching and learning. Teaching and Teacher Education, 20 (8), 817-831. 
Crandall, R. (1973). The measurement of self-esteem and related constructs. In J.P. Robinson and P. R. Shaver (Eds.), Measures of social psychological attitudes, 45-167. Ann Arbor: University of Michigan Press.

Creswell, J. W. (2008). Educational research: planning, conducting and evaluating quantitative and qualitative research. New Jersey: Pearson.

Çuhadaroglu, F. (1986). Adolesanlarda Benlik Saygısı (Yayınlanmamış yüksek lisans tezi), Hacettepe Universitesi Ankara.

Doruk, B. K. (2014). The educational approaches of Turkish pre-service elementary mathematics teachers in their first teaching practices: Traditional or constructivist?. Australian journal of teacher education, 39 (10), 8.

Emmons, R. A. (1987). Narcissism: Theory and measurement. Journal of personality and social psychology, 52 (1), 11.

Eren, A. (2009). Examining the teacher efficacy and achievement goals as predictors of Turkish student teachers' conceptions about teaching and learning. Australian Journal of Teacher Education, 34 (1), 69-87.

Fishbein, M. and Ajzen, I. (1975). Belief, attitude, intention and behaviour: An introduction to theory and research. Reading, MA: Addi-son-Wesley.

Freud, S. (1914). On Narcissism. The Standard Edition of the Complete Psychological Works of Sigmund Freud, Volume XIV (1914-1916): On the History of the Psycho-Analytic Movement, Papers on Metapsychology and Other Works, 67-102.

Friedman, I. A. (2016) Being a teacher: altruistic and narcissistic expectations of pre-service teachers, Teachers and Teaching, 22 (5), 625-648.

Gül, H. (2013). Investigation of Undergraduate Student's Self-Esteem Levels in Terms of Some Variables. Hacettepe Üniversitesi Eğitim Fakültesi Dergisi, 28 (2), 194-205.

Güneş, E. ve Bahçivan, E. (2018). A mixed research-based model for pre-service science teachers' digital literacy: Responses to "which beliefs" and "how and why they interact" questions. Computers \& Education, 118, 96-106.

Hewson, P. W. ve Kerby, H. W. (1993). Conceptions of teaching science held by experienced high school science teachers. Paper presented at the annual meeting of the National Association for Research in Science Teaching, Washington, DC. ERIC ED364426.

Kane, R., Sandretto, S. ve Heath, C. (2002). Telling half the story: A critical review of research on the teaching beliefs and practices of university academics. Review of Educational Research, 72 (2), 177-228.

Koballa, T. R, Graber, W., Coleman, D. C. and Kemp, A. C. (2000). Pro-spective gymnasium teachers' conceptions of chemistry learning and teaching. International Journal of Science Education, 22 (2), 209-224. 
Koballa, T. R., Glynn, S. M., Upson, L. and Coleman, D. C. (2005). Con-ceptions of teaching science held by novice teachers in an alternative certification program. Journal of Science Teacher Education, 16, 287-308.

Koballa, T. ve Graber, W. (2001, August). Prospective science teachers' conceptions of teaching and learning: A methodological reconsideration. In D. Psillos, P. Kariotoglou, V. Tselfes, G. Bisdikian, G. Fassoulopoulos, E. Hatzikraniotis, \& M. Kallery (Ed.), Proceedings of the 3rd International Conference on Science Education Research in the Knowledge (Volume1, pp. 115117). Thessaloniki, Greece: European Science Education Research Association.

Kohut, H. (1977). Restoration of the Self. New York: International University Press.

Lasch, C. L. (1979). The culture of narcissism. New York: Norton

Marton, F., Dall'Alba, G. and Beaty, E. (1993). Conceptions of learning. International Journal of Educational Research, 19 (3), 277-299.

Pajares, M. F. (1992). Teachers' beliefs and educational research: Cleaning up a messy construct. Review of Educational Research, 62 (3), 307-332.

Pilch, I. ve Hyla, M. (2017). Narcissism and self-esteem revisited:The relationships between the subscales of the NPI and explicit/implicit self-esteem. Polish Psychological Bulletin,48 (2) 264 278.

Raskin, R. N. ve Hall, C. S. (1979). A narcissistic personality inventory. Psychological Reports, 45(2), 590.

Raskin, R. ve Terry, H. (1988). A principal-components analysis of the Narcissistic Personality Inventory and further evidence of its construct validity. Journal of personality and social psychology, 54 (5), 890.

Rhodewalt, F., Madrian, J. C. ve Cheney, S. (1998). Narcissism, selfknowledge organization, and emotional reactivity: The effect of daily experiences on self-esteem and affect. Personality and Social Psychology Bulletin, 24, 75-87.

Rokeach, M. (1968). Beliefs, attitudes and values. San Francisco: Jossey-Bass Inc. Erişim adresi: https://lib.ugent.be/en/catalog/rug01:000979024. Erişim tarihi: 22/10/2018.

Rosenberg, M. (1965). Society and adolescent child. Princeton, NJ: Princeton University Press. https://books.google.com.tr/books. Erişim tarihi: 22/10/2018.

Rosenberg, M. (1979). Conceiving the self. New York: Basic Books

Saljö, R. (1979). Learning in the learner's perspective: Some commonsense conceptions. Gothenburg, Sweden: Institute of Education, University of Gothenburg.

Temel, D. (2008). The role of perceived social problem solving, narcissism, self-esteem and gender in predicting aggressive behaviors of high school students (Yayımlanmamış yüksek lisans tezi.) METU.

Tennen, H. ve Affleck, G. (1993). The puzzles of self-esteem: A clinical perspective. In R.F. Baumeister (Ed.), Self-esteem: The puzzle of low self-regard. (pp. 241-262). New York: Plenum Press. 
Timuroğlu, K. ve İşcan, Ö.F. (2008). İşyerinde narsisizm ve is tatmini ilişkisi. İktisadi ve idari Bilimler Dergisi, 22, (2), 239-264.

Tsai, C. C. (2002). Nested epistemologies: science teachers' beliefs of teaching, learning and science. International Journal of Science Education, 24 (8), 771-783.

Tsai, C. C. (2004). Conceptions of learning science among high school stu-dents in Taiwan: A phenomenographic analysis. International Journal of Science Education, 26 (14), 1733-1750.

Twenge, J. M. ve Campbell, W. K. (2009). The narcissism epidemic: Living in the age of entitlement. Simon and Schuster. Erişim adresi: https://www.narcissismepidemic.com, Erişim tarihi: $22 / 10 / 2018$.

Wallace, H. M. ve Baumeister, R. F. (2002). The performance of narcissists rises and falls with perceived opportunity for glory. Journal of personality and social psychology, 82 (5), 819.

Wenglinsky, H. (2002). How schools matter: The link between teacher classroom practices and student academic performance. Education policy analysis archives, 10, (12), 1-30.

Windschitl, M. (2002). Framing constructivism in practice as the negotiation of dilemmas: An analysis of the conceptual, pedagogical, cultural, and political challenges facing teachers. Review of educational research, 72 (2), 131-175.

\section{Extended Abstract}

The role of teachers' practices on the learning and achievement of students and the role of teachers' beliefs in shaping these practices led researchers to investigate the beliefs of pre-service/in-service teachers and the effects of these beliefs on their teaching behaviors. However, the unquestionable number of teachers' beliefs that can affect teaching practices requires the determination of the hierarchical relationship between these beliefs for qualified teacher education. According to Rokeach (1968), central beliefs have more relations with peripheral beliefs; so that peripheral beliefs are influenced by central beliefs. For example, one's beliefs about his/her own self (as a central belief) is one of the most important factors that direct his educational life. From this point of view, it can be thought that investigation of the effects of pre-service teachers' beliefs about their self on their preferences of teaching-learning approaches will be a worthy topic. However, self-esteem and narcissism are two of the concepts that occupy an important place in the psychology literature about self. It is known that there is a direct connection between these two concepts and that high self-esteem has a heterogeneous structure including narcissism. However, narcissism has some critical differences from high self-esteem, which seem to have important implications in the interpersonal relationships of individuals. Narcissism and self-esteem were investigated hardly in psychology literature with regards to individuals' work and daily life. It can be thought that examining the relationships between these concepts and pre-service teachers' conceptions of teaching and learning will contribute to the field of teacher education. In this context, the study was aimed to reveal the relationships among pre-service teachers' self-esteem, narcissism levels and conceptions of teaching and learning.

In the proposed model to examine the research problem; it was assumed that self-esteem had a positive effect on constructivist learning-teaching approach and predicted the traditional approach negatively. It was also assumed that the level of narcissism would predict the traditional conceptions of teaching and learning positively and the 
constructivist conceptions of teaching and learning negatively. 923 pre-service teachers participated in the study voluntarily. The data of the study were collected with three different measurement scales: Rosenberg Self-Esteem Scale, Narcissistic Personality Inventory-16 and Learning-Teaching Approach Scale. After the data collection process was completed, the data were transferred to SPSS environment. Confirmatory factor analysis was performed using AMOS to check the construct-related validity. Finally, a structural equation model analysis was performed through AMOS to examine the relationship between pre-service teachers' self-esteem, narcissism levels and conceptions of teaching and learning. When the descriptive findings of the research are examined, it can be stated that preservice teachers have relatively higher self-esteem and lower level of narcissism. The relationships among preservice teachers' self-esteem, levels of narcissism and conceptions of teaching-learning were examined through structural equation modeling analysis. It was determined that the model showed an acceptable fit $(\chi 2 / \mathrm{df}$ $=3.34, \mathrm{CFI}=0.88, \mathrm{TLI}=0.87$ and $\mathrm{RMSEA}=0.05)$. The model explains $21 \%$ and $7 \%$ of the variance in the constructivist approach and the traditional approach, and $6 \%$ of the variance in the level of narcissism.

According to the model, the self-esteem of the pre-service teachers predicts the levels of narcissism in a positive way. The level of narcissism predicts the traditional conceptions of teaching and learning positively, while it negatively predicts the constructivist conceptions of teaching and learning. On the other hand, self-esteem has a positive relation with constructivist conceptions of teaching and learning, while it negatively predicts traditional conceptions of teaching and learning. The positive relationship between self-esteem and constructivist conception can result from certain personal characteristics those mentioned in previous studies such as individuals who have high self-esteem to communicate effectively, to talk within the group and to criticize about the group approach, to be more willing to use more self-regulating skills and to be more persistence after failure. It can be assumed that pre-service teachers will give more importance to the activities of the group where knowledge is produced and the activities where students will experience process of creating information themselves. On the other hand, it can be thought that a preservice teacher, who has high level of self-esteem, described as a general assessment of a person's worthiness as a human being, is aware of his/her worthiness as a human being. From this point of view, it is possible to say that this pre-service teacher will approach to the students from the same perspective and care for them as an individual. It is known that self-esteem of narcissistic individuals is also high and this makes it difficult to investigate the relationship of self-esteem with various variables. However, narcissistic individuals differ from individuals who are not narcissistic and have high self-esteem in terms of their behavior and relations with other people. For example, the narcissistic individual may be more unsuccessful in interpersonal relations, dominant and self-centered in the community. Additionally, they have the characteristics of not being able to make empathy, obedience to others and waiting to be approved. Based on these findings in previous studies, this study was presumed, contrary to self-esteem, the level of narcissism has a positive relationship with traditional conceptions and a negative relationship with the constructivist conceptions. The narcissistic personality traits mentioned above may have led to a higher tendency of pre-service teachers to hold more traditional conceptions. According to Friedman (2016), who examined the effects of pre-service teachers' narcissistic desires on class behavior preferences, pre-service teachers with high level narcissism adopted a teacher-centered classroom control approach. More generally, the findings of this study also show that the narcissistic pre-service teachers are more prone to traditional conceptions of learning and teaching.

Constructivism has not been reflected properly to teachers' practices in the classroom despite emphasis on constructivist approaches in the education world and efforts made to promote these approaches in teacher training 
programs. Research shows that teachers' practices in the classroom and their teaching decisions have a strong relationship with their beliefs about learning and teaching. In this study, it has been pointed out that some of the beliefs of the pre-service teachers about their self (self-esteem and narcissism) may have an effect on their beliefs about teaching and learning. On the other hand, narcissism is becoming more widespread in today's world, and this situation has important consequences for societies, and as seen in our research, narcissism seems to trigger a traditional teaching and learning approach in pre-service teachers. Therefore, one of the factors that hinder the transition to constructivist practices in the classroom may be high level of narcissism of some pre-service (or inservice) teachers. From this point of view, it can be stated that further evaluation of different psychological aspects and beliefs of pre-service teachers in teaching belief systems will contribute to the field. 